\title{
GROWTH AND ECONOMIC PERFORMANCE, SOME HEMATOLOGICAL, BIOCHEMICAL AND OXIDATIVE STRESS PARAMETERS, AND CAR- CASS TRAITS OF SUMMER STRESSED CALIFORNIAN AND CROSS- BRED RABBITS AS AFFECTED BY DIETARY SUPPLEMENTATION OF FORMIC ACID
}

Tamer M. Abdel-hamid' ${ }^{1}$, Mohamed A. Omar²

${ }^{1}$ Animal Breeding and Production, Animal Wealth Development, Faculty of Veterinary Medicine, Zagazig University, Egypt, ${ }^{2}$ Veterinary Economics and Farm Management, Animal Wealth Development, Faculty of Veterinary Medicine, Zagazig University

${ }^{*}$ Corresponding author, E-mail: Omarkafafy@yahoo.com

\begin{abstract}
The aim of present study was to examine the effect dietary supplementation of formic acid on growth performance, some heamatological, biochemical and oxidative stress parameters as well as carcass traits of summer stressed Californian (CAL) and Californian $\times \operatorname{Rex}(\mathrm{CAL} \times \mathrm{RX})$ crossbred rabbits. A total of 60 rabbits 4 weeks old were allotted into $2 \times 3$ completely randomized design (two genotypes; CAL and CAL $\times$ RX and three dietary treatment; $0,0.3$ and $0.5 \%$ formic acid). Rabbits were subjected to a temperature of $32 \pm 1^{\circ} \mathrm{C}$ during the experimental period, they were slaughtered at 10 weeks of age and blood samples were collected at slaughtering. Rabbits fed diet with $0.5 \%$ formic acid had the higher final body weight $(P<0.001)$, body weight gain (BWG) $(P<0.001)$, average daily gain (ADG) $(P<0.001)$ and the lowest feed to gain ratio $(P<0.001)$ compared with those fed diet with $0.3 \%$ formic acid and the control rabbits. Rabbits fed diet supplemented with $0.3 \%$ formic acid had higher significant total protein $(P<0.001)$ and globulin $(P<0.001)$ than the control rabbits whilst, the highest significant red blood cell (RBCs), white blood cell (WBCs) count and catalase activity have been recorded in $0.5 \%$ formic acid group. Carcass traits significantly affected $(P<0.05)$ by dietary supplementation of formic acid were; hot and reference carcass weights, and dressing-out, skin, stomach, intestine, liver, hind part proportions. The effect of genotype $\times$ dietary supplement of formic acid was significant for average daily feed intake (ADFI), $(P=0.028)$, cholesterol $(P=0.001), \mathrm{Hb}(P=0.002)$, haematocrit percentage $(P=0.006)$ glutathione peroxidase $(P=0.026)$, and dressing-out\% $(P=0.028)$. Net profit for $C A L$ and $C A L \times R X$ were 8.68 and 10.34 (LE/rabbit) and for $0,0.3$ and $0.5 \%$ formic acid were $4.87,10.11$ and $13.72 \mathrm{LE} / \mathrm{rab}$ bit. In conclusion, Formic acid can be used as a dietary supplement at $0.5 \%$ of diet to improve economic efficiency, growth traits and health, immune parameters in the blood and improved the antioxidant status without any harmful effect on carcass traits.
\end{abstract}

Key words: formic acid; blood; oxidative stress; carcass; gross income 


\section{Introduction}

Rabbits can be used as a good alternative source of animal protein for humans in the developing countries (1). They characterized by high reproductive output and can digested high fibers diet such as forages and agriculture byproduct to produce high quality meat (2) These meat high in protein and low in fat (3). The problem of bacterial antibiotic resistance arises from use of antibiotics as a feed additive attracts a public health concern $(4,5)$. This fact encourages the European Union to ban the use of antibiotic as a growth promoters since 2006 (6). So other safe, natural, efficient and economic feed additives that exert the same purpose becomes very interesting.

Organic acids can be used as replacement for antibiotics in rabbits' diet (7). There are many benefits of using organic acids as a feed additives such as antifungal property, antibacterial activity against anaerobic pathogens (8), reduced mortality caused by gastrointestinal tract disease (9-11) and stimulate gastrointestinal mucosal growth (12). Also (13) observed that dietary treatment with $0.5 \%$ acetic acid or $0.5 \%$ lactic acid had a positive effect on body weight gain and feed conversion ratio. In addition to, plasma cholesterol and total lipids have been lowered in summer stressed growing New Zealand White rabbits. $(14,15)$ found that rabbits fed diet supplemented with a blend of microencapsulated formic and citric acids $0.2 \%$ in the finishing period (56-77 d) had higher significant ADG compared with control. The diet supplementation with organic acids had no effect on carcass traits (13-18) detected that inclusion of organic acids, butyric acid, calcium formate or its salts in the diet had no effect on internal organs and skin weights, but hot carcass weight and dressing-out percentage were significantly affected.

The objective of this study was to study the effect dietary supplementation with formic acid on growth performance, haematological, biochemical and oxidative stress parameters as well as carcass traits in rabbit of different genotype exposed to heat stress. In addition to this, to evaluate the economics of formic acid inclusion in rabbits' feed.

\section{Materials and methods}

Animals, diet and management

A total of $60 \mathrm{CAL}$ and $\mathrm{CAL} \times \mathrm{RX}$ of equal sex rabbits about 4 weeks old at the start of this investigation nearly homogenous with average initial body weight of $434.33 \pm 17.43$ have been subjected to $2 \times 3$ completely randomized design (two genotypes; 30 of each CAL and CAL $\times$ RX, and threes dietary treatments; 20 of each $0,0.3$ and $0.5 \%$ of diet formic acid) and ten replicates. The ingredients of the basal diet was firstly prepared then divided into three equal parts. The formic acid was added to the last two parts at 0.3 and $0.5 \%$ of the diet.

The proximate chemical composition of the basal diets were determined according to AOAC (19). The experimental rabbits were ear tagged, housed in well ventilated house in flat deck arranged metal cages (two rabbit of the same genetic group per cage; one male and one female), the dimensions of the cage were ( $45 \times$ $45 \times 35 \mathrm{~cm})$. The manure was regulatory disposed on a daily bases and a metal feeder and a drip nipple drinker have been provided for each cage. Ration and water were offered for ad libitum consumption. This experiment has been performed during summer months (July and August) of Egypt and inside temperature has been maintained to be averaged $32 \pm 1{ }^{\circ} \mathrm{C}$. A fourteen hours of day light has been maintained. The fattening period was 6 weeks (from 4 to 10 weeks of age).

\section{Growth performance}

The initial and the final body weights were recorded on individual bases while feed intake were recorded on cage bases and the feed to gain ratio were calculated.

\section{Carcass traits}

All the experimental rabbits were slaughtered at 10 weeks of age in the same day and all the slaughtered procedures follow the world rabbit science association recommendations (20). The rabbits were fasted to about 12 hours. Firstly, the live weights were recorded, then rabbits were stunned and the two jugulars were served. Blood, skin including distal paws and 
tail, intestine, stomach were weighed, the remaining was the hot carcass, then chilled in ventilated room at $4^{\circ} \mathrm{C}$ for 24 hour and then head, liver, heart, lungs, esophagus, trachea, thymus gland, and kidney free of perirenal fat were removed as reference carcass. Finally, the reference carcass was divided into three anatomical parts (fore, mid and hind parts).

Blood haematological, biochemical and oxidative stress parameters while slaughtering rabbits two blood samples per rabbit have been collected, on ethylenediaminetetra-acetic acid (EDTA) for haematological studies and one without anticoagulants for plasma separation for biochemical and oxidative stress parameters. Red blood cell count (RBC), white blood cell count (WBC), h aemoglobin ( $\mathrm{Hb}$ ) concentration and haematocrit\% were performed as previously described (21-23). For serum separation the blood samples were centrifuges $3000 \mathrm{~g}$ for $15 \mathrm{~min}$ at a temperature of $15-24^{\circ} \mathrm{C}$ and the samples were stored at $-20^{\circ} \mathrm{C}$ until they were assayed. Total proteins, albumin, triglycerides and cholesterol were determined photometrically by using commercial kits and as previously described (24). The serum level of glutathione peroxidase, superoxide dismutase, catalase activity and lipid peroxidase were measured as previously detailed $(25,26)$.

\section{Statistical analysis}

A general linear mode (GLM) of (27) was utilized to analyze the data of growth performance, blood parameters, carcass traits and economic efficiency parameters. The following model used:

$$
\mathrm{Y}_{\mathrm{ijk}}=\mu+\mathrm{G}_{\mathrm{i}}+\mathrm{T}_{\mathrm{j}}+(\mathrm{GT})_{\mathrm{ij}}+\mathrm{e}_{\mathrm{ijk}}
$$

Where $Y_{i j k}$ is an observation on $n$th rabbit of each trait, $\mu$ is the overall mean, $G_{i}$ is the fixed effect of $i$ th breed ( $i=1$ and 2, i.e. CAL and CAL $\times \mathrm{RX}), \mathrm{T}_{\mathrm{j}}$ is the fixed effect of dietary treatment with formic acid $(j=1,2$ and 3, i.e. 0 , 0.3 and $0.5 \%$ of diet), $\mathrm{GT}_{\mathrm{ij}}$ is the effect of interaction between genotype and dietary treatment with formic acid level and $\mathrm{e}_{\mathrm{ijk}}$ is the random residual effect. The comparisons between means were performed using (28) at $P<0.05$.

\section{Economic parameters}

The following indices were calculated per each groups of rabbits: Total fixed costs (TFC), total costs $(\mathrm{TC})(30,31)$. Total return (NR), net profit (NP) and economic efficiency (EE)(2932).

\section{Results}

\section{Growth performance}

CAL rabbits had heavier final body weight than CAL $\times \operatorname{RX}(P=0.009)$ (Table 1). Rabbits fed diet with $0.5 \%$ formic acid had the highest significant final body weight $(P<0.001)$, BWG $(P<0.001)$, ADG $(P<0.001)$ and the lowest feed to gain ratio $(P<0.001)$ compared with those fed diet with $0.3 \%$ formic acid and the control rabbits (Table 1). The effect of genotype $\times$ dietary supplementation was non-significant on all growth traits except for ADFI (Table 1).

Blood heamatological, biochemical and oxidative stress parameters

The CAL genotype had higher significant serum triglycerides concentration $(P=0.003)$ than $\mathrm{CAL} \times \mathrm{RX}$, however, $\mathrm{CAL} \times \mathrm{RX}$ rabbit had higher significant WBC count $(P<0.001)$ and catalase activity $(P<0.001)$ than their CAL counterparts (Table 2). Regardless the rabbits' genetic group, those fed diet with $0.3 \%$ formic acid had higher significant total protein $(P<0.001)$ and globulin $(P<0.001)$ than the control rabbits. In contrast, they had lower significant albumin/globulin ratio $(P<0.001)$ than the $0 \%$ formic acid group (Table 3 ). The control rabbits had the highest significant albumin $(P<0.001)$ albumin/globulin ratio, whilst they recorded the lowest significant total protein, globulin, RBC $(P<0.001)$, WBC count $(P<0.001)$ and catalase activity compared with those fed diet supplemented with $0.3 \%$ and $0.5 \%$ formic acid. The highest significant RBC, WBC count and catalase activity have been determined in $0.5 \%$ formic acid group (Table 2).

The only blood parameters showed a significant genotype $\times$ dietary supplementation with formic acid were; cholesterol $(P=0.001), \mathrm{Hb}$ $(P=0.002)$, haematocrit percentage $(P=0.006)$ and Glutathione peroxidase $(P=0.026)$ (Table 
3). CAL rabbits supplemented with $0.3 \%$ formic acid had the highest cholesterol and Glutathione peroxidase concentration whereas, the same genetic group fed diet with $0.5 \%$ formic acid had the highest $\mathrm{Hb}$ concentration. Rabbits of CAL $\times$ RX genetic group had received $0.5 \%$ acid had depicted the highest haematocrit percentage.

\section{Carcass traits}

Heavier hot and reference carcasses ( $P=0.001$ and $P=0.003$ ) have been recorded in CAL rabbits compared with CAL $\times$ RX (Table 4). Rabbits supplemented with $0.5 \%$ formic acid had the highest significant hot and reference carcass weights $(P=0.001)$, and hind part percentage $(P=0.018)$. However, those fed diet supplemented with $0.3 \%$ formic acid had the highest stomach $(P=0.001)$, intestine $(P<0.001)$, liver $(P=0.005)$ and periscapular fat percentages $(P=0.008)$. On the other hand, the control rabbits had the highest skin $\%(P=0.016)$ (Table 4$)$. The effect of genotype $\times$ dietary supplementation was non-significant on all carcass traits with the exception of dressing out \% $(P=0.028)$ (Table 4).

\section{Economic parameters}

Significant genotype $\times$ dietary treatment interaction with formic acid had been detected on total feed intake and total feed cost per rabbit $(P<0.05)$, but if the fixed effects of dietary formic acid level and breed considered separately, it is cleared that rabbits fed on diet with $0.5 \%$ formic acid revealed lower total feed intake and total feed cost per rabbit than either control or $0.3 \%$ formic acid rabbit groups, but not significant. The effect of genotype $\times$ dietary treatment interaction on total feed intake and total feed cost per rabbit was non-significant $(P>0.05)$ and different economic measures are presented in (Table 5). Where Net profit for CAL and CAL $\times$ RX were 8.68 and 10.34 (LE/rabbit) and for $0,0.3$ and $0.5 \%$ formic acid were 4.87 , 10.11 and $13.72 \mathrm{LE} /$ rabbit

Table 1: Effects of genotype and formic acid on growth performance of rabbits

\begin{tabular}{|c|c|c|c|c|c|c|c|c|c|c|}
\hline \multirow{2}{*}{ Variable } & \multicolumn{3}{|c|}{ Genotype (G) } & \multicolumn{4}{|c|}{$\begin{array}{l}{ }^{1} \text { Dietary treatment with } \\
\text { formic acid (T) }\end{array}$} & \multicolumn{3}{|c|}{ P-value } \\
\hline & CAL & $\begin{array}{c}\mathrm{CAL} \times \\
\mathrm{RX}\end{array}$ & sem & $0 \%$ & $0.3 \%$ & $0.5 \%$ & sem & G & $\mathrm{T}$ & $\begin{array}{c}\mathrm{G} \times \\
\mathrm{T}\end{array}$ \\
\hline Rabbits, No. & 30 & 30 & & 20 & 20 & 20 & & & & \\
\hline Initial body weight, g & 415.12 & 453.53 & 25.26 & 408.78 & 446.29 & 447.91 & 30.93 & 0.287 & 0.602 & 0.987 \\
\hline Final body weight, $g$ & 1718.03 & 1676.80 & 10.82 & $1528.74^{c}$ & $1716.43^{b}$ & $1847.09^{\mathrm{a}}$ & 13.26 & 0.009 & $<0.001$ & 0.180 \\
\hline Body weight gain, $g$ & 1276.69 & 1250.05 & 27.85 & $1113.22^{c}$ & $1275.13^{b}$ & $1401.76^{\mathrm{a}}$ & 34.11 & 0.502 & $<0.001$ & 0.753 \\
\hline Average daily gain, g/d & 30.39 & 29.764 & 0.66 & $26.50^{c}$ & $30.36^{\mathrm{b}}$ & $33.37^{\mathrm{a}}$ & 0.81 & 0.502 & $<0.0$ & 0.754 \\
\hline $\begin{array}{l}\text { Average daily feed in- } \\
\text { take, } \mathrm{g} / \mathrm{d}\end{array}$ & 118.62 & 117.29 & 2.05 & 119.66 & 118.28 & 115.928 & 2.51 & 0.650 & 0.573 & 0.028 \\
\hline Feed to gain ratio & 4.077 & 4.01 & 0.104 & $4.58^{\mathrm{a}}$ & $4.02^{\mathrm{b}}$ & $3.531^{\mathrm{c}}$ & 0.12 & 0.673 & $<0.001$ & 0.862 \\
\hline
\end{tabular}

Means within the same row within the dietary treatment category not sharing the same superscript letter were significantly different at $P<0.05$. ${ }^{1}$ Dietary treatment with formic acid at $0,0.3$ and $0.5 \%$ of diet; $\mathrm{CAL}=$ Californian; $\mathrm{CAL}$ $\times \mathrm{RX}=$ Californian $\times$ Rex; $\mathrm{G} \times \mathrm{T}=$ genotype $\times$ dietary treatment interaction; sem $=$ standard error of mean 
Table 2: Some blood biochemical, haematological and oxidative stress parameters of Californian and Californian $\times$ Rex rabbits at 10 weeks of age as affected by formic acid. Results of significant genotype $\times$ dietary treatment interaction were summarized in Table 4

\begin{tabular}{|c|c|c|c|c|c|c|c|c|c|c|}
\hline \multirow{2}{*}{ Variable } & \multicolumn{3}{|c|}{ Genotype $(\mathrm{G})$} & \multicolumn{4}{|c|}{$\begin{array}{l}{ }^{1} \text { Dietary treatment with } \\
\text { formic acid }(\mathrm{T})\end{array}$} & \multicolumn{3}{|c|}{ P-value } \\
\hline & CAL & $\begin{array}{l}\mathrm{CAL} \times \\
\mathrm{RX}\end{array}$ & sem & $0 \%$ & $0.3 \%$ & $0.5 \%$ & sem & G & $\mathrm{T}$ & $\mathrm{G} \times \mathrm{T}$ \\
\hline Rabbits, No. & 30 & 30 & & 20 & 20 & 20 & & & & \\
\hline Total protein $(\mathrm{g} / \mathrm{dl})$ & 5.70 & 5.67 & 0.045 & $5.30^{\mathrm{b}}$ & $5.93^{\mathrm{a}}$ & $5.82^{\mathrm{a}}$ & 0.055 & 0.626 & $<0.001$ & 0.355 \\
\hline Albumin $(\mathrm{g} / \mathrm{dl})$ & 3.48 & 3.46 & 0.028 & $3.61^{\mathrm{a}}$ & $3.42^{b}$ & $3.38^{b}$ & 0.034 & 0.534 & $<0.001$ & 0.075 \\
\hline Globulin $(\mathrm{g} / \mathrm{dl})$ & 2.21 & 2.21 & 0.048 & $1.68^{\mathrm{b}}$ & $2.51^{\mathrm{a}}$ & $2.43^{\mathrm{a}}$ & 0.059 & 0.922 & $<0.001$ & 0.482 \\
\hline $\begin{array}{c}\text { Albumin / Globulin } \\
\text { ratio }\end{array}$ & 1.67 & 1.62 & 0.055 & $2.16^{\mathrm{a}}$ & $1.37^{\mathrm{b}}$ & $1.41^{\mathrm{b}}$ & 0.067 & 0.549 & $<0.001$ & 0.391 \\
\hline $\begin{array}{l}\text { Triglycerides } \\
\text { (mg/dl) }\end{array}$ & 16.78 & 16.73 & 0.013 & 16.73 & 16.76 & 16.75 & 0.017 & 03 & 0.378 & 0.901 \\
\hline $\mathrm{RBC}_{\mathrm{S}}\left(\times 10^{6} / \mathrm{mm}^{3}\right)$ & 4.04 & 4.07 & 0.059 & $3.79^{\mathrm{b}}$ & $4.12^{\mathrm{a}}$ & $4.26^{\mathrm{a}}$ & 0.072 & 0.709 & $<0.001$ & 0.555 \\
\hline $\begin{array}{l}\text { White blood cells } \\
\left(\times 10^{9 /} \mathrm{L}\right)\end{array}$ & 8.95 & .59 & 0.11 & $6.96^{\mathrm{c}}$ & $9.14^{\mathrm{b}}$ & $11.70^{\mathrm{a}}$ & 0.13 & $<0.001$ & $<0.001$ & 0.485 \\
\hline $\begin{array}{l}\text { Lipid peroxidase } \\
\left(\mathrm{nmol} / \mathrm{mol} \mathrm{x} 10^{6}\right)\end{array}$ & 15.27 & 15.30 & 0.15 & 15.13 & 15.40 & 15.34 & 0.19 & .880 & 0.577 & 0.199 \\
\hline $\begin{array}{l}\text { Superoxide dis- } \\
\text { mutase }(\mathrm{m} / \mathrm{mg})\end{array}$ & 84.62 & 85.73 & 1.69 & 85.95 & 86.17 & 83.41 & 1.98 & 0.629 & 0.554 & 0.749 \\
\hline Catalase $(\mathrm{mg} / \mathrm{g})$ & 393.74 & 578.14 & 3.21 & $428.13^{c}$ & $484.09^{b}$ & $545.61^{\mathrm{a}}$ & 3.93 & $<0.001$ & $<0.001$ & 0.228 \\
\hline
\end{tabular}

Means within the same row within the dietary treatment category not sharing the same superscript letter were significantly different at $P<0.05 . \mathrm{RBC}_{\mathrm{S}}=$ red blood cell count $\left(\times 10^{6} / \mathrm{mm}^{3}\right) ;{ }^{1}$ dietary treatment with formic acid at $0,0.3$ and $0.5 \%$ of diet $\mathrm{CAL}=$ Californian; $\mathrm{CAL} \times \mathrm{RX}=$ Californian $\times$ Rex; $\mathrm{G} \times \mathrm{T}=$ genotype $\times$ dietary treatment interaction; sem $=$ standard error of mean

Table 3: The effects due to interactions between genotype and formic acid on some blood biochemical, haematological and oxidative stress parameters at 10 weeks of age

\begin{tabular}{|c|c|c|c|c|c|c|c|c|c|c|}
\hline \multirow{2}{*}{ Variable } & \multicolumn{3}{|c|}{ CAL } & \multicolumn{3}{|c|}{$\mathrm{CAL} \times \mathrm{RX}$} & \multirow{2}{*}{ sem } & \multicolumn{3}{|c|}{$P$-value } \\
\hline & ${ }^{1}$ Control & ${ }^{2} 0.3 \%$ & ${ }^{3} 0.5 \%$ & Control & $0.3 \%$ & $0.5 \%$ & & $\mathrm{G}$ & $\mathrm{T}$ & $\mathrm{G} \times \mathrm{T}$ \\
\hline $\begin{array}{c}\text { Cholesterol } \\
(\mathrm{mmol} / \mathrm{L})\end{array}$ & $0.867^{\mathrm{c}}$ & $0.962^{\mathrm{a}}$ & $0.910^{\mathrm{b}}$ & $0.926^{\mathrm{b}}$ & $0.940^{\mathrm{ab}}$ & $0.937^{\mathrm{ab}}$ & 0.010 & 0.012 & $<0.001$ & 0.001 \\
\hline $\mathrm{Hb}(\mathrm{g} / \mathrm{dL})$ & $11.283^{\mathrm{a}}$ & $10.901^{\mathrm{b}}$ & $11.476^{\mathrm{a}}$ & $10.908^{\mathrm{b}}$ & $11.354^{\mathrm{a}}$ & $11.252^{\mathrm{a}}$ & 0.117 & 0.612 & 0.051 & 0.002 \\
\hline $\begin{array}{l}\text { Haemato- } \\
\text { crit percent- } \\
\text { age }\end{array}$ & $29.36^{\mathrm{b}}$ & $30.11^{\mathrm{a}}$ & $30.04^{\mathrm{a}}$ & $30.11^{\mathrm{a}}$ & $29.86^{\mathrm{a}}$ & $30.20^{\mathrm{a}}$ & 0.148 & 0.079 & 0.037 & 0.006 \\
\hline $\begin{array}{l}\mathrm{GP}(\mathrm{mg} \\
\text { protein) }\end{array}$ & $110.002^{\mathrm{ab}}$ & $120.531^{\mathrm{a}}$ & $98.028^{\mathrm{ab}}$ & $103.461^{\mathrm{ab}}$ & $95.453^{b}$ & $112.881^{\mathrm{ab}}$ & 7.156 & 0.343 & 0.939 & 0.026 \\
\hline
\end{tabular}

Means within the same row not sharing the same superscript letter were significantly different at $P<0.05$. CAL = Californian; CAL $\times \mathrm{RX}=$ Californian $\times \mathrm{Rex} ;{ }^{1,2,3}$ dietary treatment with formic acid at $0,0.3$ and $0.5 \%$ of diet; $\mathrm{Hb}$ $(\mathrm{g} / \mathrm{dL})=$ haemoglobin concentration measured by gram in deciliter; $\mathrm{G} \times \mathrm{T}=$ genotype $\times$ dietary treatment interaction; sem $=$ standard error of mean. GP $=$ Glutathione peroxidase. Number of rabbits per group is $10(5$ males and 5 females). 
Table 4: The carcass traits of Californian and Californian $\times$ Rex rabbits at 10 weeks of age as affected by formic acid level

\begin{tabular}{|c|c|c|c|c|c|c|c|c|c|c|}
\hline \multirow[b]{2}{*}{ Variable } & \multicolumn{2}{|c|}{ Genotype (G) } & \multirow[b]{2}{*}{ sem } & \multicolumn{3}{|c|}{$\begin{array}{l}{ }^{1} \text { Dietary treatment with } \\
\text { formic acid }(\mathrm{T})\end{array}$} & \multirow[b]{2}{*}{ sem } & \multicolumn{3}{|c|}{$P$-value } \\
\hline & CAL & $\begin{array}{l}\text { CAL } \times \\
\text { RX }\end{array}$ & & $0 \%$ & $0.3 \%$ & $0.5 \%$ & & G & $\mathrm{T}$ & $\mathrm{G} \times \mathrm{T}$ \\
\hline Rabbits, No. & 30 & 30 & & 20 & 20 & 20 & & & & \\
\hline $\begin{array}{l}\text { Live body } \\
\text { weight, g }\end{array}$ & 1718.03 & 1676.80 & 10.82 & $1528.74^{\mathrm{c}}$ & $1716.43^{b}$ & $1847.09^{\mathrm{a}}$ & 13.26 & 0.009 & $<0.001$ & 0.180 \\
\hline $\begin{array}{l}\text { Hot carcass, } \\
\mathrm{g}\end{array}$ & 1106.65 & 1036.40 & 11.66 & $945.85^{\mathrm{c}}$ & $1056.32^{\mathrm{b}}$ & $1212.40^{\mathrm{a}}$ & 14.28 & 0.001 & 0.001 & 0.674 \\
\hline $\begin{array}{l}{ }^{2} \text { Reference } \\
\text { carcass, g }\end{array}$ & 881.74 & 846.35 & 7.94 & $757.41^{\mathrm{c}}$ & $882.71^{\mathrm{b}}$ & $952.02^{\mathrm{a}}$ & 9.73 & 0.003 & 0.001 & 0.221 \\
\hline $\begin{array}{l}{ }^{3} \text { Dressing- } \\
\text { out, } \%\end{array}$ & 51.23 & 50.45 & 0.82 & 49.54 & 51.41 & 51.56 & 1.01 & 0.152 & 0.005 & 0.028 \\
\hline \multicolumn{11}{|c|}{$\%$ of Live weight } \\
\hline Blood & 3.07 & 3.00 & 0.107 & 3.06 & 3.16 & 2.89 & 0.131 & 0.665 & 0.336 & 0.821 \\
\hline Skin & 17.71 & 17.46 & 0.32 & $18.46^{\mathrm{a}}$ & $17.52^{\mathrm{ab}}$ & $16.77^{\mathrm{b}}$ & 0.39 & 0.599 & 0.016 & 0.264 \\
\hline Stomach & 5.67 & 5.43 & 0.167 & $5.77^{\mathrm{a}}$ & $6.01^{\mathrm{a}}$ & $4.88^{\mathrm{b}}$ & 0.20 & 0.314 & 0.001 & 0.264 \\
\hline Intestine & 10.50 & 10.49 & 0.23 & $10.65^{\mathrm{a}}$ & $11.26^{\mathrm{a}}$ & $9.59^{\mathrm{b}}$ & 0.28 & 0.974 & $<0.001$ & 0.945 \\
\hline \multicolumn{11}{|c|}{$\%$ of hot carcass } \\
\hline Liver & 4.59 & 4.76 & 0.18 & $4.13^{\mathrm{b}}$ & $5.21^{\mathrm{a}}$ & $4.70^{\mathrm{ab}}$ & 0.22 & 0.509 & 0.005 & 0.966 \\
\hline Heat \& lung & 1.62 & 1.65 & 0.04 & 1.56 & 1.72 & 1.62 & 0.05 & 0.727 & 0.087 & 0.667 \\
\hline Kidney & 1.06 & 1.04 & 0.03 & 1.04 & 1.08 & 1.02 & 0.04 & 0.689 & 0.610 & 0.629 \\
\hline Head & 10.45 & 10.49 & 0.13 & 10.65 & 10.42 & 10.33 & 0.16 & 0.835 & 0.368 & 0.464 \\
\hline \multicolumn{11}{|c|}{$\%$ of reference carcass } \\
\hline PSF & 0.44 & 0.44 & 0.01 & $0.41^{\mathrm{b}}$ & $0.50^{\mathrm{a}}$ & $0.42^{\mathrm{b}}$ & 0.02 & 0.936 & 0.008 & 0.856 \\
\hline PRF & 2.18 & 2.19 & 0.06 & 2.10 & 2.28 & 2.17 & 0.08 & 0.924 & 0.326 & 0.437 \\
\hline Fore part & 37.14 & 37.29 & 0.42 & 37.03 & 37.40 & 37.21 & 0.51 & 0.793 & 0.879 & 0.699 \\
\hline Mid part & 21.21 & 21.32 & 0.39 & 21.91 & 21.16 & 20.73 & 0.47 & 0.844 & 0.223 & 0.893 \\
\hline Hind part & 38.59 & 38.24 & 0.25 & $38.06^{\mathrm{b}}$ & $38.01^{\mathrm{b}}$ & $39.17^{\mathrm{a}}$ & 0.31 & 0.347 & 0.018 & 0.815 \\
\hline
\end{tabular}

Means within the same row within the dietary treatment category not sharing the same letter were significantly different at $P<0.05 . \mathrm{CAL}=$ Californian; $\mathrm{CAL} \times \mathrm{RX}=$ Californian $\times \mathrm{Rex} ;{ }^{1}$ dietary treatment with formic acid at $0,0.3$ and $0.5 \%$ of diet; $\mathrm{G} \times \mathrm{T}=$ genotype $\times$ dietary treatment interaction; ${ }^{2}$ reference carcass $=$ chilled carcass minus head, liver, heart, lungs, esophagus, trachea, thymus gland, and kidney free of perirenal fat ${ }^{3}{ }^{3}$ calculated in relation to reference carcass; PSF $=$ periscapular fat; $\mathrm{PRF}=$ Perirenal fat. 
Table 5: Effects of genotype and formic acid level on some economic parameters and efficiency for Californian and Californian $\times$ Rex rabbits

\begin{tabular}{|c|c|c|c|c|c|c|c|c|c|c|}
\hline \multirow{2}{*}{ Variable } & \multicolumn{3}{|c|}{ Genetic group $(\mathrm{G})$} & \multicolumn{4}{|c|}{$\begin{array}{l}{ }^{1} \text { Dietary treatment with } \\
\text { formic acid }(\mathrm{T})\end{array}$} & \multicolumn{3}{|c|}{$P$-value } \\
\hline & CAL & $\begin{array}{c}\text { CAL } \times \\
\text { RX }\end{array}$ & sem & $0 \%$ & $0.3 \%$ & $0.5 \%$ & sem & G & $\mathrm{T}$ & $\mathrm{G} \times \mathrm{T}$ \\
\hline Rabbits, No. & 30 & 30 & & 20 & 20 & 20 & & & & \\
\hline $\begin{array}{l}\text { Total feed intake per rab- } \\
\text { bit, g }\end{array}$ & 4982.13 & 4926 & 86.36 & 5025 & 4968.09 & 4868.95 & 105.78 & 0.650 & 0.573 & 0.028 \\
\hline $\begin{array}{l}{ }^{2} \text { Total feed cost per rabbit, } \\
\text { LE }\end{array}$ & 22.42 & 22.16 & 0.38 & 22.61 & 22.35 & 21.91 & 0.47 & 0.650 & 0.573 & 0.028 \\
\hline${ }^{3}$ Price per rabbit, LE & 54.9 & 5 & 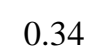 & 40.72 & $54.92^{\mathrm{b}}$ & Jy & 0 . & 0.009 & $<0.001$ & 0 . \\
\hline${ }^{4}$ Total $\mathrm{F}$ & 56.0 & & & $50.20^{c}$ & $56.30^{\mathrm{b}}$ & $60.30^{\mathrm{a}}$ & 0.78 & 0.002 & $<0.001$ & 0.170 \\
\hline${ }^{5}$ Total variable cos & 40.42 & 39.16 & 0.23 & 40.33 & 41.19 & 41.58 & 0.47 & 0.530 & 0.523 & 0.122 \\
\hline${ }^{6}$ Total fi & 5.00 & 5.00 & 0.14 & 5.00 & 5.00 & 5.00 & 0.02 & 0.11 & 0.321 & 0.180 \\
\hline Total costs(LE/rabbit) & 47.42 & 44.16 & 0.22 & 45.33 & 46.19 & 46.58 & 0.33 & 0.221 & 0.273 & 0.128 \\
\hline Net profit (LE/rabbit) & 8.68 & 10.34 & 0.03 & $4.87^{\mathrm{c}}$ & $10.11^{\mathrm{b}}$ & $13.72^{\mathrm{a}}$ & 0.22 & 0.03 & 0.001 & 0.008 \\
\hline Net Profit/ $t$ & 0.14 & & 0.00 & & & 0.294 & 0.02 & 0.12 & 0.101 & 0.11 \\
\hline Net Profit / total returns & 0.154 & 0.189 & 0.021 & $0.097^{\mathrm{c}}$ & $0.179^{\mathrm{b}}$ & $0.227^{\mathrm{a}}$ & 0.002 & 0.001 & 0.002 & 0.028 \\
\hline
\end{tabular}

Means within the same row within the dietary treatment category not sharing the same superscript letter were significantly different at $P<0.05 .{ }^{1}$ Dietary treatment with formic acid at $0,0.3$ and $0.5 \%$ of diet; $\mathrm{CAL}=$ Californian; CAL $\times \mathrm{RX}=$ Californian $\times$ Rex; LE $=$ Egyptian pound $;{ }^{2}$ calculated as total feed intake per rabbit multiplied by price per kg of feed $(4.5 \mathrm{LE}) ;{ }^{3}$ calculated as final body weight multiplied by price per $\mathrm{kg}$ of live rabbit sold $(32 \mathrm{LE}) ; \mathrm{G} \times \mathrm{T}=$ genotype $\times$ dietary treatment interaction; sem $=$ standard error of mean ${ }^{4}$ Calculated as price of rabbit plus price of litter. ${ }^{5}$ Calculated as price of rabbit and all medicaments (LE/ rabbit). ${ }^{6}$ Calculated as rent, employments and other fixed costs (LE/ rabbit).

\section{Discussion}

The improvement in body weights, BWG, and ADG and the worseness in the feed to gain ratios after supplementation with organic acids (formic acid) has been seen in this study are in agreement with those reported previously $(33,34)$. The first authors found feed intake to decrease and consequently, improvement feed conversion with the supplementation of diet with citric acid from $0.5 \%$ and up to $2.0 \%$ whereas, the second author recorded improvement of body weight gains with $0.5 \%$ fumeric, citric, and malic acids. However, no response has been recorded on weight gain, but feed intake was lowered and thus the feed conversion was improved in rabbits fed citric acid at $\mathrm{g} / \mathrm{kg}$ diet (35). Dietary treatment with $0.5 \%$ acetic acid or $0.5 \%$ lactic acid had a positive effect on body weight gain and feed conversion ratio of summer stressed growing New Zealand White rabbits (13). Similarly, positive effects of organic acids on growth traits have been reported by (36). The addition of $1.5 \%$ fumaric acid to rabbits' diet improved daily gain and feed efficiency $(37,34)$.
This positive effect of formic acid on growth performance could be attributable to the unfavorable environment to pathogens in the cecum and ileum that the formic acid exert by lowering the ph. Also, it acts as substrates in the intermediary metabolites, increase gastric protein digestion and availability of some elements that complex with (17).

There is no doubt that the average final body weights had been recorded in the present study were below the average expected for these animal and for these ages and this could be attributed to the higher temperature to which the rabbits were exposed and this previously documented $(38,39)$. Genetic group $\times$ dietary treatment was non-significant on final body weight (40).In a study on New Zealand $\times$ Californian mixed-sex rabbits, rabbits fed diet supplemented with a blend of microencapsulated formic and citric acids $0.2 \%$ in the finishing period $(56-77 \mathrm{~d})$ had higher significant $(P=0.019)$ ADG (48.0 g) compared with control (43.9 g) (8) Rabbits fed diet with organic acids at 1.0 $\mathrm{g} / \mathrm{kg}$ depicted higher significant body weights at 14 weeks of age and daily body weight gains 
at 7-14 weeks age interval and lower significant feed conversion ratios compared with control.

\section{Blood heamatological, biochemical and ox- idative stress parameters}

The significant differences between purebred CAL and CAL $\times$ RX crossbred rabbits in the serum level of triglycerides are in accordance with the findings of (41). Whereas, other authors reported that genetic group to have a non-significant effect on blood haematological and biochemical parameters $(40,36)$.

In agreement with (13) they found that dietary supplementation with organic acid had a significant effect on serum globulin and cholesterol concentration. However, (13) observed that dietary supplementation of $0.5 \%$ acetic acid or $0.5 \%$ lactic acid had a non-significant effects on plasma total protein, albumin, globulin and total lipids, but they significantly lowered plasma cholesterol concentration compared with Control rabbits. The dietary treatment of rabbits with organic acids at $1.0 \mathrm{~g} / \mathrm{kg}$ had no effect on blood biochemical parameters. Also, blood biochemical parameters not significantly differed in rabbits fed diet supplemented with mixture of formic and propionic acids and those on the basal diet only $(16,41)$.

The exposure of rabbits to high temperature leads to stress on these rabbits, leading to increased free radicals and lipid oxidation and these free radicals can lead to irreversible damage to cells if not treated (42).Antioxidant enzymes have an important role in the animals in getting rid of free oxygen radicals that are released as a result of heat stress (43). The rabbits fed diet supplemented with Mucuna Pruriens leaf meal had higher and significant glutathione peroxidase and catalase in the blood these enzymes help these rabbit to cope with stress-induced oxidative destruction (1)

\section{Carcass traits}

The higher significant hot and reference carcass weights of CAL than that of CAL $\times \mathrm{RX}$ are consistent with those reported by (38), they detected significant differences among genetic groups for the majority carcass traits. Also, the commercial and the reference carcass weights were higher in purebred rabbits than crossbreds at $30^{\circ} \mathrm{C}$.

The higher periscapular in rabbits fed on diet with $0.3 \%$ formic acid collaborate those reported previously (13) who found higher abdominal fat in rabbits supplemented with $0.5 \%$ lactic acid than control but not significant. The diet supplementation with organic acids had no effect on carcass traits $(13,16,17)$.Inclusion of organic acids, butyric acid, calcium formate or its salts in the diet had no effect on internal organs and skin weights, but hot carcass weight and dressing out percentage were significantly affected.

Any contrasting results with previous studies regarding the effect of organic acid on carcass traits could be explained by different experimental animal, methods of calculations, slaughter age and/or experimental procedures. The non-significant effect of genetic group $\times$ dietary treatment on carcass traits are in agreement with those reported by (40).

\section{Economic parameters}

The results showed significant effect of formic acid at $0.5 \%$ where the total returns CAL and CAL $\times$ RX were 56.01 and 54.5 (LE/rabbit) and for $0,0.3$ and $0.5 \%$ formic acid were 50.2 , 56.3 and 60.30 LE/rabbit respectively. Meanwhile Net profit for CAL and CAL $\times \mathrm{RX}$ were 8.68 and 10.34 (LE/rabbit) and for $0,0.3$ and $0.5 \%$ formic acid were $4.87,10.11$ and 13.72 LE/rabbit on the side of economic efficiency measurements the Net profit/ total returns were significant at $\mathrm{p} \leq 0.05$ for $\mathrm{CAL}$ and $\mathrm{CAL} \times \mathrm{RX}$ were 0.15 and 0.18 and for $0,0.3$ and $0.5 \%$ formic acid were $0.09,0.17$ and 0.22 that indicated the economic importance of using formic acid at $0.5 \%$ for rabbits.

\section{Conclusion}

The dietary supplementation with formic acid at $0.5 \%$ of diet has been associated with an improvement in growth traits, health, immunity and antioxidant blood parameters of summer stressed CAL and CAL $\times$ RX rabbits without any negative effect on carcass traits. In addition to, the economic efficiency was found to be higher in rabbits fed diet with $0.5 \%$ formic acid. 
Significant genotype $\times$ dietary supplementation with formic acid interactions have been detected for ADFI, cholesterol, $\mathrm{Hb}$, haematocrit percentage, glutathione peroxidase, dressingout $\%$,total feed intake, total feed cost, net profit per rabbit and net profit/ total return.

\section{Conflict of interest}

The authors declare that they have no conflict of interest.

\section{References}

1. Lukefahr S, Cheeke P. Rabbit project development strategies in subsistence farming systems: 1 . Practical considerations World Animal Review 1991; 68: 60-70

2. McNitt J, Lukefahr S, Cheeke P, PattonN. Rabbit production. 9th edn. (British Library: London) BMC Veterinary Research 2013; 7: 17466148 .

3. Dalle Zotte A. Perception of rabbit meat quality and major factors influencing the rabbit carcass and meat quality. Livestock Production Science 2002; 75(1): 11-32.

doi:10.1016/S0301-6226(01)00308-6.

4. Allen S, Boerlin P, Janecko N. Antimicrobial resistance in generic Escherichia coli isolates from wild small mammals living in swine farm, residential, landfill, and natural environments in Southern Ontario, Canada. Applied and Environmental Microbiology 2011; 882-8.

5. Azza M, Kamal T, Abd El-Hakim, Amal M. Influence of some organic acids supplementation on growth performance and some biochemical parameters in growing Rabbits. Egypt. J. Comp. Path. \& Clinic. Path. 2008; 21: $174-89$

6. Hassanin K, Youssef I. The effect of dietary supplementation of some antioxidants on performance, oxidative stress, and blood parameters in broilers under natural summer conditions. J. World's Poult. Res., 2014; 4: 10-19.

7. Falcão-e-Cunha L, Castro-Solla L, Maertens L, Marounek M, Pinheiro V, Freire L, Mourao J. Alternatives to antibiotic growth promoters in rabbit feeding: a review. World Rabbit Sci. 2007;15: 12740.

8. Rotruck J, Pope A, Ganther H, Hafeman D, Hoekstra W.Selenium: Biochemical role as a component of glutathione peroxidase. Science 1973; 179: 588-90.

9. Huber H, Ziegler D, Pflûger V. Prevalence and characteristics of methicillin resistant coagulase-negative staphylococci from livestock, chicken carcasses, bulk tank milk, minced meat, and contact persons 2011.

10. El-Adawy M, El-Aziz M A, El-Shazly K, Ali N G, El-Magd M A. Dietary propionic acid enhances antibacterial and immunomodulatory effects of oxytetracycline on Nile tilapia, Oreochromis niloticus, Environmental Science and Pollution Research. DOI:10.1007/s11356-018-3206-5 2018.

11. Kishawy A, Amer S, Osman A, Elsayed S, Abd El-Hack M, Swelum A, Ba-Awadh H, Saadeldin I. Impacts of supplementing growing rabbit diets with whey powder and citric acid on growth performance, nutrient digestibility, meat and bone analysis, and gut health. AMB Express 2018; 8(1) : 86-94.

12. Cardinali R, Rebollar P, Dal Bosco A, Cagiola M, Crotti S, Scicutella N, Rutili D, Castellini C. Integrazione alimentare di acidi organici ed oli essenziali microincapsulati nel controllo delle infezioni enteriche del coniglio. In Proc.: Giornate di Coniglicoltura ASIC, Forlì, Italy, 2007; 137.

13. Scapinello C, de-Faria H, Furlan A, Pedro $\mathrm{M}$. Influence of different levels of fumaric acid and acetic acid on the growing rabbits performance. Revista Brasileira de Zootecnia, 1998; 27: 945-50.

14. Huber H, Ziegler D, Pflûger V. Prevalence and characteristics of methicillin resistant coagulase-negative staphylococci from livestock, chicken carcasses, bulk tank milk, minced meat, and contact persons 2011.

15. Michelan A, Scapinello C, Natali M, Furlan A, Sakaguti E, Faria H, Santolin M. Hernandes A.B. Utilização de probiotico, ácido orgânico e antibiótico em dietas para coelhos em crescimento: ensaio de digestibilidade, avaliação da morfometria intestinal e desempenho. Rev. Bras.Zootec., 2002; 31: 2227-37.

16. Dorra T, Ismail F, Sherif K, Rabie M. Growth performance of fattening rabbits as affected by stocking density and added dietary organic acids. J. Animal and Poultry Prod. 2013; 4(5): 249-62.

17. Coles E. Veterinary Clinical Pathology. WB Saunders, Philadelphia, USA, 4th 1986

18. Kirchgessner M, Roth Fx. Ergotrope effekte durch organisch sauren in der ferkelaufzucht und schweinemast.Ubersichten zur Tierenahrung, 1988; 16 (93): 1-8.

19. AOAC. Association of Official Agricultural Chemists. Official methods of analysis. Washington. DC. 1990

20. Blasco A, Ouhayoun J. Harmonization of criteria and terminology in rabbit meat research: revised proposal. World Rabbit Science 1993; 4: 939. 
21. El-Magd M A, Khamis A, Nasr Eldeen S K, Ibrahim W M, Salama A F. Trehalose enhances the antitumor potential of methotrexate against mice bearing Ehrlich ascites carcinoma, Biomedicine \& Pharmacotherapy 2017; 92: 870-8.

22. Singh K. Effect of heat stress on blood constituents in crossbred heifers. The Indian Journal of Animal Sciences 1983; 53: 353-5

23. Bauer J. Numerical evaluation of red blood, white blood cells and platelets, part III, hematology. In 'Clinical laboratory methods and diagnosis'. 7th edn. (Eds S Frankel, S Reitman, AC Somen Wirth) Vol. 1, pp. 1970; 399-402.

24. Saleh A A, Amber K, El-Magd M A, Atta M S, Mohammed A A, Ragab M M, Abd El-Kader H. Integrative effects of feeding Aspergillus awamori and fructooligosaccharide on growth performance and digestibility in broilers: promotion muscle protein metabolism, Biomed Res Int 2014; 2014: 946859.

25. Abdelhady D, El-Abasy M, Abou-Asa S, Elbialy Z, Shukry M, Hussein A, Saleh A, El-Magd M. The ameliorative effect of Aspergillus awamori on aflatoxin B1-induced hepatic damage in rabbits, World Mycotoxin Journal 2017; 10(4): 363-73. Ohkawa H, Ohishi N, Yagi K. Assay for lipid peroxides in animal tissues by thiobarbituric acid reaction. Anal. Biochem. 1979; 95: 351-8.

26. SAS .Statistics analysis system user's guide, release 9.2.' SAS Institute Inc.: Cary, NC 2008.

27. Duncan D. The multiple range and F. tests. Biometrics 1955; 11: 1-45. doi:10.2307/3001478.

28. Atallah S. Economic and productive efficiency of veterinary management in dairy farms. Ph.D. Degree, Animal Husbandry Department, Faculty of Veterinary Medicine Alexandria University 1997.

29. El-Tahawy A. Cattle diseases and their effects on economic and productive efficiency of dairy farms. Ph.D. Faculty of Veterinary Medicine, Alexandria University 2007.

30. Mohamed A, Abdel-Hamid T. Economic Evaluation of using Dried Tomato Pomace (DTP) for Ducks . Proc. of the 6th Animal Wealth Research Conf. in the Middle East \& North Africa MENAJAS) ISSN online 2013; 2356-6302

31. Omar M. Economic and productive efficiency of poultry farms in relation to veterinary inputs. M.V.Sc. Thesis, Fac. Vet. Med. 2003.

32. El-Kerdawy D. Acidified feeds for growing rabbits. Egyptian J. Rabbit Sci. 1996; 6: 143-56.

33. Scapinello C, de-Faria H, Furlan A, Pedro $M$. Influence of different levels of fumaric acid and acetic acid on the growing rabbits performance. Revista Brasileira de Zootecnia, 1998; 27: 945-50.

34. El-Allawy H. The use of bio-feed additives to improve rabbit performance. Ph.D. Thesis, Cairo Univ. 2001.

35. Khalil M, El-Zarie M.Genetic groups comparisons for growth, carcass, meat quality and blood parameters in program of synthesizing new lines of rabbits. In 'Proceeding of 10th world rabbit congress, 3-6 September,Sharm El-Sheikh, Egypt, World Rabbit Science Association. pp. 2012; 2419.

36. Michelan A, Scapinello C, Natali M, Furlan A, Sakaguti E, Faria H, Santolin M. Hernandes A.B. Utilização de probiotico, ácido orgânico e antibiótico em dietas para coelhos em crescimento: ensaio de digestibilidade, avaliação da morfometria intestinal e desempenho. Rev. Bras.Zootec., 2002; 31: 2227-37.

37. Okab A, El-Banna S. Physiological and biochemical parameters in New-Zealand white male rabbits during spring and summer seasons. Egyptian Journal of Basic and Applied Physiology 2003; 2: 289-300.

38. Okab A, El-Banna S, Koriem A. Influence of environmental temperatures on some physiological and biochemical parameters of male New-Zealand rabbits. Slovak Journal of Animal Science 2008; 41: 12-19.

39. Al-Dobaib S, Khalil M, Hashad M, Al-Saef A.Growth, carcass and caecal traits in $\mathrm{V}$-Line and crossbred rabbits fed diets containing discarded dates. World Rabbit Science 2007; 15: 81-90.

40. Abdel-Azeem A, Abdel-Azim A, Darwish A, Omar E. Haematological and biochemical observations in four pure breeds of rabbits and their crosses under Egyptian environmental conditions. World Rabbit Science.2010; 18:103-10.

41. Meineri G, Giacobini M, Forneris G. Evaluation of physiological parameters of the plasma oxidative status in rabbits. J. Appl. Anim. Res. 2017; 45: 315-9

42. Li S, Zhao M, Jiang T, Lv W, Gao S, Zhou Y, Miao Z. Growth performance and antioxidant status of growing rabbits fed on diets supplemented with Eucommia ulmoides leaves. World Rabbit Sci. 2018; 26: 35-41. 